\title{
Comparative Studies on Organic and Inorganic N, P, K, and Zn- Fertilization for Wheat Crop in Northern Delta Soils.
}

\author{
M. S. Genedy ${ }^{1}$; A. M.G. Ewis ${ }^{2}$, M. M.Sobh ${ }^{2}$ and S. Genaidy ${ }^{3}$ \\ 1- Wheat Res. Dept.; Field Crop Research Institute, Agric. Res. Center, Egypt. \\ 2- Soil \&Water Dept. Fac. of Technology and Development, Zagazig University, Egypt. \\ 3- Soil Fert. and Plant Nutrition Res. Dept.; Soil Water and Environment Research Institute, ARC, Egypt. \\ Correspondence author: ashrafewis@ hotmail.com
}

\begin{abstract}

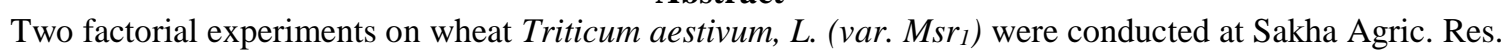
Station on a clay soil for two successive seasons of (2015/2016; 2016/2017). Factors1 comprised 3 organic manuring $\left(0,24\right.$ and $\left.48 \mathrm{~m}^{3} \mathrm{ha}^{-1}\right)$ and 5 mineral fertilizations (none, N, NP, NPK and NPK Zn). Mineral rates (kg $\mathrm{ha}^{-1}$ ) :240 kg N (as urea),32 kg P (as Ca-superphosphate), $48 \mathrm{~kg} \mathrm{~K}$ (as K-sulphate) and $12 \mathrm{~kg} \mathrm{Zn} \mathrm{(as} \mathrm{Zn-sulphate).}$ Application of organic manure (as compost) increased wheat grain and straw yields as well as grains protein content. Also all the values of the previously mentioned studied parameters increased by applying mineral fertilizers. The highest positive effect was by applying the high compost + NPKZn giving increases of 106 to 114 $\%$ in grain yield and increases occurred also in contents of protein as well as $\mathrm{N}, \mathrm{P}, \mathrm{K}$ and $\mathrm{Zn}$ contents.
\end{abstract}

Keywords: Organic manure, Mineral fertilization, Compost, NPKZn fertilizers, Wheat (var. Msrl ).

\section{Introduction}

Wheat is the most important food crop in Egypt. More than 1050 thousand hectares are cultivated with wheat, with average productivity of $6.5 \mathrm{Mg} \mathrm{ha}^{-1}$ with application of various fertilizers (Genaidy and Hegazy, 2001). Organic manuring has safer effects on soil properties. Mineral fertilization for wheat in optimum recommended rates may maximize yields (Genaidy, 2010). Nitrogen fertilization of maize increases plant growth and yield (Bleken et al. 2009, Pavlík et al. 2010). Liu Dandan and Yan Shi (2013), observed that the number of kernels per spike and grain yield increased with nitrogen application. The positive effect of phosphorus and potassium aggregate of the functions played by nutrients in mitigating negative effects of biotic and abiotic stresses. Plants provided with sufficient amounts of phosphorus and potassium are can improve water efficiency (Ma et al. 2006).Potassium is an indispensable component during the main stages of protein biosynthesis. Its deficiency leads to a decrease in protein content in plant (RICE 2007). Arshad et al. (2016) reported that $10 \mathrm{~kg} \mathrm{Zn} \mathrm{ha}{ }^{-1}$ increased wheat spike length, 1000 grain weight and grain yield. The objective of this investigation was to assess the effects of organic manuring with or without mineral fertilization of $\mathrm{N} \mathrm{P}$ $\mathrm{K}$ Zn nutrients.

\section{Materials And Methods}

Two field experiments on wheat crop (Triticum aestivum, L.) var. Msr (1) were carried out at Sakha Agricultural Research Station during 2015/2016 and 2016/2017 seasons in two different experimental sites. The design was a randomized complete block, factorial ( 2 factors). Factor 1 was organic fertilization using 3 rates: 0,24 and $48 \mathrm{~m}^{3} \mathrm{ha}^{-1}$. Factor 2 was mineral fertilization using 5 treatments of none, $\mathrm{N}$, NP, NPK and NPKZn. Rates ( $\mathrm{kg}$ element $\left.\mathrm{ha}^{-1}\right)$ being $240 \mathrm{~N} ; 32 \mathrm{P} ; 48 \mathrm{~K} ; 12 \mathrm{Zn}$. Treatments were in 4 replicates. Soils of both experiments were clay, slight alkaline and non-saline. Table 1 shows the main properties of the soils. Analyses of plant and soil were done according to Chapman and Pratt (1961) and Black (1965). The plot area was $6 \mathrm{~m}^{2}$. Organic manure as compost, $\mathrm{P}$ and $\mathrm{K}$ were added during soil preparation. $\mathrm{P}$ form was Ca-superphosphate $(68 \mathrm{~g} \mathrm{P}$ $\left.\mathrm{kg}^{-1}\right)$; $\mathrm{N}$ form was urea $\left(460 \mathrm{~g} \mathrm{~N} \mathrm{~kg}^{-1}\right)$; $\mathrm{K}$ form was $\mathrm{K}$ sulphate $\left(400 \mathrm{~g} \mathrm{~K} \mathrm{~kg}^{-1}\right)$; $\mathrm{Zn}$ form was $\mathrm{ZnSO}_{4} .7 \mathrm{H}_{2} \mathrm{O}$ (227 $\mathrm{g} \mathrm{Zn} \mathrm{kg}^{-1}$ ). Main properties of the compost are given in Table 2. Wheat (Triticum aestivum, L.) var. $\mathrm{Msr}_{1}$ was seeded on 17/11/2015 in season 1 and $20 / 11 / 2016$ in season 2 . Nitrogen was applied in two equal doses; the first was before the first irrigation (30 days after seeding); and the second was before the second irrigation ( 30 days after the first).

All the agronomic practices were applied according to the recommended methods. Harvesting was conducted on 13/5/2016 and on 11/5/2017; for the two seasons, respectively.

\section{Results And Discussion}

The data obtained from the two experiments are presented in Tables 3 and 4 .

\section{a- Main effects:}

1- Organic manuring :

As shown in Table 3; increasing organic manure rate ( $\mathrm{M}_{1}{ }^{\prime 2} 24 \mathrm{~m}^{3} \mathrm{ha}^{-1 "}$ and $\mathrm{M}_{2}$ "48 $\mathrm{m}^{3} \mathrm{ha}^{-1 "}$ ) led to increases in wheat grain and straw yields as well as grain / straw ratios. Average increases of grain yield were 18.7 and $36.0 \%$ due to $\mathrm{M}_{1}$ and $\mathrm{M}_{2}$ respectively in season 1, comparable increases in season 2 were 7.9 and $26.1 \%$ respectively. Increases in straw yield followed a pattern similar to that of the grain yield. 
Grains / straw ratio increased only upon applied the high rate of manure. With regard to wheat grainsprotein content, it increased with the increase in organic manuring. Increases due to the low and high rates were 21.7 and $25.5 \%$ respectively in season 1 and 8.9 and $13.9 \%$ respectively in season 2 . Abou ElEnein et al.(2008), hammad et al.(2008) and Zeidan et al. (2009) reported that organic manuring increases crop yields and protein content.

\section{2- N, P, K and Zn-mineral fertilization Effects:}

Table 3 reveals that wheat grains and straw yields as well as grains / straw ratio increased by applying mineral fertilizers of N, NP, NPK and N P $\mathrm{K} Z \mathrm{Zn}$. The highest response was that upon application of NPKZn. Grain yield increase by mineral fertilization averaged 14.2, 23.3, 26.7and 35.1\% for the 4 treatment respectively in season 1 . Comparable increases in season 2 averaged 16.4, 32.0, 38.7and $45.7 \%$ respectively. With respect to contents of $\mathrm{N} \mathrm{P}$ $\mathrm{K}$ and $\mathrm{Zn}$ in grains results indicate pattern rather similar to that of grain yield. These results are in agreement with those obtained by Genaidy et al (2007), Abbas et al.(2009), and Atia (2012).
As for wheat grains- protein content, data presented in Table 3 show that application of mineral fertilizers significantly increased the values of this parameter in the same trend taken by the other studied characters. Zeidan et al. (2009), reported increased contents of protein in wheat grains upon application of $\mathrm{N}$ and organic manure

\section{b- Effect of different combination treatments:}

Table 4 indicates increased positive response due to applying any ore more of the organic or mineral fertilizer. The lowest grain yield increase of 42.2 and $29.9 \%$ in season 1 and 2 respectively occurred with applying $\mathrm{N}$ while the highest of 113.7 and $105.6 \%$ in season 1 and 2 respectively occurred with the high organic manure + N P K Zn. As for contents of N P K and $\mathrm{Zn}$ in wheat grains results show increases due to application of manure and mineral fertilizer singly or combined. Lowest increase in $\mathrm{N}$ content was with $\mathrm{N}$ application (3.8\% increase) in season 1and by $\mathrm{N} \mathrm{P}$ application $(7.8 \%$ ) in season 2. Highest increase in $N$ contents occurred with high manure + N P K Zn which caused increases of $54.1 \%$ in season 1 and $31.8 \%$ in season 2 .

Table 1. Some physical and chemical characteristics of the two experimental sites before wheat planting during the two growth seasons.

\begin{tabular}{|c|c|c|}
\hline Soil fertility characteristic & Site $_{1}\left(1^{\text {st }}\right.$ season $)$ & Site $_{2}\left(2^{\text {nd }}\right.$ season $)$ \\
\hline Mechanical analysis (\%) & 24.20 sand, 24.10 silt, 51.70 clay & 23.30 sand, 24.60 silt, 52.10 clay \\
\hline Soil texture class & Clay & Clay \\
\hline Saturation percentage (SP) \% & 70 & 72 \\
\hline EC ( Soil paste extract) $\mathrm{dSm}^{-1}$ & 3.86 & 3.90 \\
\hline Soluble cations $\left(\mathrm{mmole}^{-1}\right)$ & $\begin{array}{ll}\mathrm{Ca}^{2+}=6.15 ; & \mathrm{Mg}^{2+}=5.75 \\
\mathrm{Na}^{+}=13.00 ; & \mathrm{K}^{+}=1.70\end{array}$ & $\begin{array}{ll}\mathrm{Ca}^{2+}=6.25 ; & \mathrm{Mg}^{2+}=6 \\
\mathrm{Na}^{+}=13.20 ; & \mathrm{K}^{+}=1.80\end{array}$ \\
\hline Soluble anions $\left(\mathrm{mmole}^{-1}\right)$ & $\begin{aligned} \mathrm{CO}_{3}{ }^{2-} & =0.00 ; \quad \mathrm{HCO}_{3}{ }^{-}=13.00 \\
\mathrm{SO}_{4}{ }^{2-} & =9.90 ; \quad \mathrm{Cl}^{-}=5.70\end{aligned}$ & $\begin{array}{l}\mathrm{CO}_{3}{ }^{2-}=0.00 ; \mathrm{HCO}_{3}{ }^{-}=16.00 \\
\mathrm{SO}_{4}{ }^{2-}=8.35 ; \mathrm{Cl}^{-}=6.70\end{array}$ \\
\hline Soil - pH (1:2.5) & 7.86 & 7.91 \\
\hline $\mathrm{CaCO}_{3}\left(\mathrm{~g} \mathrm{~kg}^{-1}\right)$ & 18.9 & 20.0 \\
\hline O.M $\quad\left(\mathrm{g} \mathrm{kg}^{-1}\right)$ & 16.5 & 16.0 \\
\hline Soil-CEC $\left(\mathrm{cmol}_{\mathrm{c}} \mathrm{kg}^{-1}\right)$ & 32.0 & 30.0 \\
\hline Available $\mathrm{N}, \mathrm{P}, \mathrm{K}, \mathrm{Zn}\left(\mathrm{mg} \mathrm{kg}^{-1}\right)$ & & \\
\hline $\mathrm{N}$ & 31.0 & 28.2 \\
\hline $\mathrm{P}$ & 21.0 & 18.0 \\
\hline $\mathrm{K}$ & 312.0 & 363.0 \\
\hline $\mathrm{Zn}$ & 0.77 & 0.68 \\
\hline
\end{tabular}

Table 2. Main properties of the tested organic manure at the two growth seasons.

\begin{tabular}{lll}
\hline organic manure characteristics & Site $_{1}\left(1^{\text {st }}\right.$ season $)$ & Site $_{2}\left(2^{\text {nd }}\right.$ season $)$ \\
\hline Moisture content $(\%)$ & 29.0 & 30.0 \\
Bulk density $\left(\mathrm{Mg} \mathrm{m}^{-3}\right)$ & 0.423 & 0.415 \\
Organic matter \% & 37.93 & 41.43 \\
Organic carbon \% & 22.0 & 23.91 \\
Total nitrogen g kg-1 & 11.2 & 13.7 \\
C/N ratio & 19.6 & 18.0 \\
pH $(1: 10$ extract, w/v) & 7.83 & 7.92 \\
EC $(1: 10$ extract $)$ & 1.72 & 1.37 \\
Total $-\mathrm{P} \mathrm{g} \mathrm{kg}^{-1}$ & 4.78 & 6.81 \\
Total $-\mathrm{K} \mathrm{g} \mathrm{kg}$ & 18.4 & 25.3 \\
Total $-\mathrm{Zn}\left(\mathrm{mgkg}^{-1}\right)$ & 0.96 & 1.47 \\
\hline
\end{tabular}


Table 3. Main effects of organic and mineral fertilization on wheat yield, -N P K Zn and protein contents in grain for the two growth seasons.

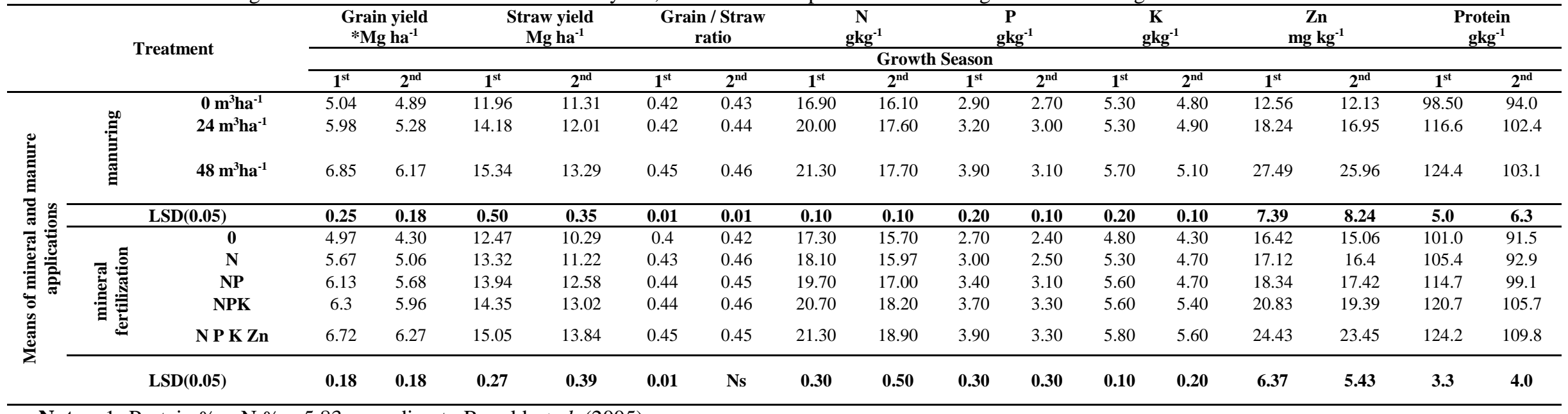

Notes: 1 - Protein $\%=\mathrm{N} \%$ x 5.83 according to Ronald et al. (2005).

2- Mineral rates $\left(\mathrm{kg} \mathrm{ha}^{-1}\right) \mathrm{N}: 240 ; \mathrm{P}: 32 ; \mathrm{K}: 48 ; \mathrm{Zn}: 12$.

3- Megagram $(\mathrm{Mg})=10^{6} \mathrm{~g}$ 
Table 4. Results of the 25 treatment combinations regarding effects of manure and mineral fertilizers

\begin{tabular}{|c|c|c|c|c|c|c|c|c|c|c|c|c|c|c|c|}
\hline \multirow{2}{*}{\multicolumn{2}{|c|}{ Treatment }} & \multicolumn{2}{|c|}{$\begin{array}{c}\text { Grain yield } \\
\mathrm{Mg} \mathrm{ha}^{-1}\end{array}$} & \multicolumn{2}{|c|}{$\begin{array}{c}\text { Straw yield } \\
\text { Mg ha }^{-1} \\
\end{array}$} & \multicolumn{2}{|c|}{$\begin{array}{c}\mathbf{N} \\
\text { gkg }^{-1}\end{array}$} & \multicolumn{2}{|c|}{$\begin{array}{c}\mathbf{P} \\
\text { gkg-1 }^{-1} \\
\end{array}$} & \multicolumn{2}{|c|}{$\begin{array}{c}\text { K } \\
\text { gkg-1 }^{-1}\end{array}$} & \multicolumn{2}{|c|}{$\begin{array}{c}\mathrm{Zn} \\
\mathrm{mg} \mathrm{kg}^{-1} \\
\end{array}$} & \multicolumn{2}{|c|}{$\begin{array}{c}\begin{array}{c}\text { Protein } \\
\text { gkg-1 }^{-1}\end{array} \\
\end{array}$} \\
\hline & & & & & & & & \multicolumn{4}{|c|}{ Growth Season } & & & & \\
\hline $\begin{array}{l}\text { Organic fert. } \\
\mathrm{m}^{3} \mathbf{h a}^{-1}\end{array}$ & $\begin{array}{c}\text { Mineral fert. } \\
\text { kg ha }^{-1}\end{array}$ & $1^{\text {st }}$ & $2^{\text {nd }}$ & $1^{\text {st }}$ & $2^{\text {nd }}$ & $1^{\text {st }}$ & $2^{\text {nd }}$ & $1^{\text {st }}$ & $2^{\text {nd }}$ & $\mathbf{1}^{\text {st }}$ & $2^{\text {nd }}$ & $1^{\text {st }}$ & $2^{\text {nd }}$ & $1^{\text {st }}$ & $2^{\text {nd }}$ \\
\hline $\mathbf{0}$ & 0 & 3.54 & 3.31 & 9.42 & 9.46 & 15.70 & 14.80 & 2.40 & 2.30 & 4.40 & 4.00 & 10.93 & 10.50 & 91.5 & 86.3 \\
\hline $\mathbf{0}$ & $\mathbf{N}$ & 5.04 & 4.30 & 11.12 & 11.14 & 16.30 & 14.10 & 2.60 & 2.20 & 5.30 & 4.40 & 11.73 & 11.2 & 95.0 & 82.2 \\
\hline $\mathbf{0}$ & NP & 5.25 & 5.44 & 11.96 & 11.31 & 16.70 & 15.90 & 2.90 & 3.00 & 5.60 & 4.90 & 11.8 & 11.76 & 97.4 & 92.7 \\
\hline $\mathbf{0}$ & NPK & 5.46 & 5.43 & 12.95 & 11.71 & 17.80 & 17.70 & 3.20 & 3.00 & 5.60 & 5.30 & 12.35 & 12.00 & 103.8 & 103.2 \\
\hline 0 & N P K Zn & 5.88 & 5.99 & 14.33 & 12.90 & 18.00 & 18.10 & 3.40 & 3.10 & 5.70 & 5.50 & 16.00 & 15.17 & 104.9 & 105.5 \\
\hline 24 & 0 & 5.04 & 4.25 & 13.46 & 9.89 & 18.00 & 16.20 & 2.50 & 2.40 & 4.80 & 4.70 & 12.67 & 11.00 & 104.9 & 94.4 \\
\hline 24 & $\mathbf{N}$ & 5.54 & 4.82 & 13.89 & 10.50 & 18.80 & 17.00 & 2.70 & 2.50 & 5.30 & 4.90 & 13.50 & 12.83 & 109.6 & 99.1 \\
\hline 24 & NP & 6.27 & 5.34 & 14.16 & 12.87 & 20.60 & 17.30 & 3.30 & 3.30 & 5.50 & 4.30 & 16.17 & 14.80 & 120.1 & 100.9 \\
\hline 24 & NPK & 6.35 & 5.95 & 14.55 & 12.99 & 20.90 & 18.40 & 3.60 & 3.50 & 5.40 & 5.20 & 21.73 & 20.14 & 121.8 & 107.3 \\
\hline 24 & N P K Zn & 6.70 & 6.01 & 14.83 & 13.79 & 21.70 & 18.90 & 4.00 & 3.10 & 5.30 & 5.50 & 27.12 & 26.00 & 126.6 & 110.2 \\
\hline 48 & 0 & 6.33 & 5.36 & 14.52 & 11.54 & 18.30 & 16.10 & 3.20 & 2.50 & 5.20 & 4.30 & 25.66 & 23.67 & 106.7 & 93.9 \\
\hline 48 & $\mathbf{N}$ & 6.45 & 5.89 & 14.93 & 12.05 & 19.10 & 16.70 & 3.60 & 2.90 & 5.40 & 4.70 & 26.14 & 25.18 & 111.4 & 97.4 \\
\hline 48 & NP & 6.85 & 6.27 & 15.72 & 13.59 & 21.70 & 17.80 & 3.90 & 3.10 & 5.60 & 5.00 & 27.06 & 25.70 & 126.5 & 103.8 \\
\hline 48 & NPK & 7.09 & 6.50 & 15.56 & 14.38 & 23.40 & 18.30 & 4.20 & 3.40 & 5.80 & 5.6 & 28.41 & 26.05 & 136.4 & 106.7 \\
\hline 48 & N P K Zn & 7.58 & 6.80 & 15.99 & 14.85 & 24.20 & 19.50 & 4.40 & 3.60 & 6.30 & 5.80 & 30.17 & 29.18 & 141.1 & 113.7 \\
\hline \multicolumn{2}{|c|}{$\operatorname{LSD}(0.05)$} & 0.50 & 0.45 & 0.79 & 0.35 & 0.70 & 0.60 & 0.20 & 0.10 & 0.20 & 0.3 & 0.67 & 0.70 & 3.7 & 3.6 \\
\hline
\end{tabular}

1- Protein \% = N \% x 5.83 according to Ronald et al. $(2005)$.

2- Mineral rates (kg ha-1) N: 240; P:32;K:48; Zn: 12.

3- Megagram $(\mathrm{Mg})=10^{6} \mathrm{~g}$ 


\section{Conclusions:}

According to the previous results; it could be concluded that:

1- For such alluvial soils; they have to be manured with composts at 24 to $48 \mathrm{~m}^{3} \cdot \mathrm{ha}^{-1}$ singly or combined with the recommended mineral N-, P-, Kand $\mathrm{Zn}$ fertilizers for realizing the highest contents of protein and N P K Zn in grains as well as wheat grain yield .

2- The beneficial effects of the organic manure would be:

a- Improving soil physical; bio-chemical; subsequent soil fertility and nutritional properties.

b- The slow release and continuous supplying of most nutrients in available forms for grown plants.

c- Increasing the absorption efficiencies of $\mathrm{N}, \mathrm{P}, \mathrm{K}$, and $\mathrm{Zn}$ nutrients for growth plants.

\section{References}

Abbas, Gh.; Jamil M.and Hussain, F.2009. Nutrient uptake, growth and yield of wheat (Triticum aestivum, L.) as affected by zinc application rates. Iner. J. Agric. and Biol.11 (4):389-396.

Abou El-Enein, S.; Mosalem, S.and El-Raies, S. 2008. Effect of composted plant residues on the availability of some nutrients in newly reclaimed soils. Egypt. J. Soil Sci. 48(3):293-304.

Arshad, M.; Adnan, M.; Ahmed, S.; Khan, A-K.; Ali, I.; Ali, M.; Al,i A.; Khan, A.; Kamal, M. A.; Gul, F. and Khan, M. A. 2016. Integrated effect of phosphorus and zinc on wheat crop. AmericanEurasian J. Agric. Environ. Sci. 16 (3): 455-459.

Atia, R. H. 2012. Effect of nitrogen fertilization levels on phosphorus absorption by some wheat varieties in Delta Region soils, Egypt. J. Soil Sci. and Agric. Eng. Mans. Univ., 3(4) : 429-441.

Black, C. A. 1965. Methods of soil analysis (ed.1), Amer. Soc. Agron. Inc, Pub. Madison, Wi., USA.

Bleken, M.A., Herrmann, A.; Haugen, L.E.; Taube, F.and Bakken, L. 2009: SPN: A model for the study of soil-plant nitrogen fluxes in silage maize cultivation. European J. of Agron., 30: 283-295.

Chapman, H. D. and Pratt, P. F. 1961. Methods of analysis for soil, plants and waters. Div. of Agric. Sci., California Univ., Berkely, USA.

Dandan, L. and Shi, Y.2013. Effects of different nitrogen fertilizer on quality and yield in winter wheat. Adv. J. Food Sci. and Tech. 5(5): 646-649.
Genaidy, S.; Abd El-Mageed, A.; Abo El-Fotoh, H. and El-Hamadi, Kh. 2007. Economic and optimum mineral fertilization for some cereal crops in north Delta soils, Egypt. Arab Conf. Soils \& Water Management for Sustainable. Agric. Develo. (1011 April, 2007), Faculty of Agric. Mansura Univ. Egypt.

Genaidy, S. and Hegazy, M. 2001. Research and application facts in plant nutrition in Arabic "AlDar Al-Arabia for pub., Nsr City; Cairo, Egypt.

Genaidy, S.A. M. 2011. Research and application bases in soil chemistry and fertility in Arabic AlDar Al-Arabia for pub., Nsr City; Cairo, Egypt.

Hammad, S.; Selim, E. and El-Shazly, M. 2008. Nitrogen and potassium status in soil as affected by farmyard manure, potassium fertilizer levels and silicate bacteria. J. Agric. Sci. Mansura. Univ. 33(1): 835-846.

Jackson, M.L. 1972. Soil chemical analysis. Printice Holl of India, New Delhi, India.

Ma, Q.; Niknam, S.R. and Turner D.W. 2006. Responses of osmotic adjustment and seed yield of Brassica napus and B. junacea to soil water deficit at different growth stages. Aust. J. Agric. Res. 57: 221-226.

Pavlík, M.; Pavlíková, D.; Balík, J.and Neuberg, M. 2010. The contents of amino acids and sterols in maize plants growing under different nitrogen conditions. Plant, Soil and Enviro. 56: 125-132.

Rice R. 2007. The physiological role of minerals in the plant. 9-30. In: Mineral nutrition and plant disease. DATNOFF et al eds APS, Minnesota, USA, $278 \mathrm{pp}$.

Richards, L.A. 1954 Diagnosis and improvement of saline and alkaline soils. USDA hand book 60 , USA.

Ronaled, E.W.; Acree, T.E.; Deckar, E.A.; Penner, M.H.; Reid, D.S.; Schwartz, S.J. ; Shoemaker, C. F.; Smith, D. and Sporns, P. 2005. Hand Book of food analytical chemistry pub. by Wiley, J. and Sons, Inc., Hoboken, New Jersey Pub. Simultaneously in Canada.

Zeidan, E.; Abd El-Hameed, I. and Waly, A. 2009. Effect of nitrogen and organic fertilization on yield, yield attributes and protein content of some wheat cultivars under newly reclaimed saline soil conditions. Zagazig $4^{\text {th }}$ Conf. on Recent Tech. Agric.; pp: 298-307. 
دراسات مقارنة التسميد العضوي و المعدني لعناصر النيتروجين و الفوسفور و البوتاسيوم و الزنك علي محصول القمح في أرضي شمال الالتا.

محمد سعيد جنيدي1 - أشرف محمد جوده عويس2 - محمود صبح2 - سعبيد جنيدي3 الفئا.

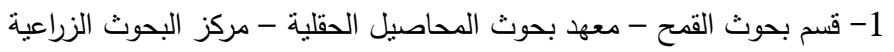

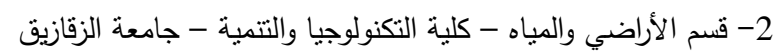

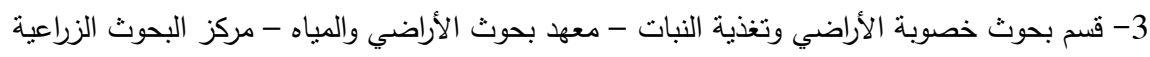

أجريت تجربتان حقليتان علي محصول القمح ( صنف مصر 1 ) في تربة طينية بمحطة البحوث الزراعية بسخا - محافظة كفر الثيخ خلال موسمي

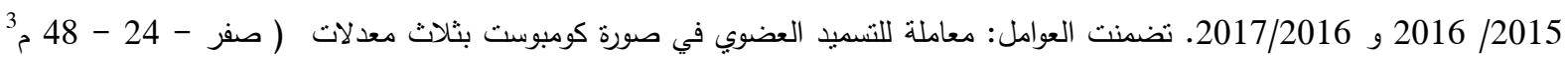

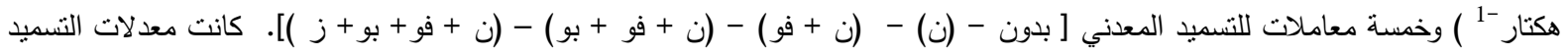

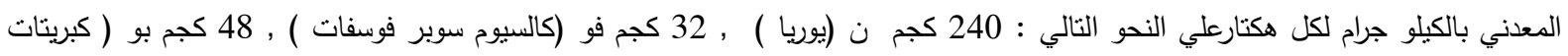

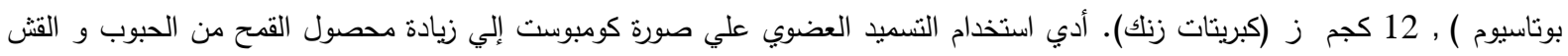

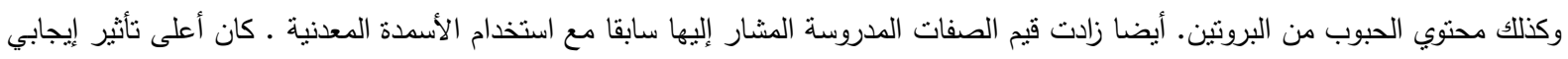
ناتج عن استخدام المعدلات المرتفعة من الكومبوست + (ن + فو + بو + ز ) حيث أعطت زيادات في محصول الحبوب مقدارها 106 و 114 \% و و

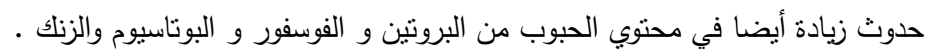

